\title{
異時性肺癌に対する外科治療成績
}

\author{
小野憲司 1 杉尾賢二 1 安田 学 1 菅谷将-1・ \\ 浦本秀隆 $1 \cdot$ 花桐武志 $1 \cdot$ 安元公正 1
}

要旨一一目的. 異時性肺癌は根治性とともに残存肺機能を考慮した上で術式を決定しなければならない. 当科で経験 した異時性肺癌の臨床的背景因子と術式, 予後を検討した. 対象と方法. 1994 年 4 月から 2005 年 12 月までに原発性肺 癌切除例 815 例のうち, 異時性肺癌と診断し外科的治療を行った 22 例 $(2.7 \%)$ を対象とした. 結果. 第一癌では, 病 理病期 IA 期 11 例, IB 期 5 例, IIB 期 1 例, IIIA 期 4 例, IV 期 1 例であり, 第二癌では, IA 期 14 例, IB 期 3 例, IIB 期 2 例, IIIA 期 1 例，IIIB 期 2 例であった．平均最大腫瘍径は第一癌が $31.8(12 \sim 77) \mathrm{mm}$, 第二癌は $19.3(5 \sim 50) \mathrm{mm}$ と第二癌で有意に小さかった $(\mathrm{p}=0.001)$. 第一癌の術式は全例肺葉切除以上であったが, 第二癌では残存肺機能を考慮 し, 15 例で縮小手術を行った．第二癌術後の 5 年生存率は $63.9 \%$ であり, 第二癌の病理病期別 5 年生存率は, IA 期で $92.9 \%$ ，IB 期以上で $0 \%$ と，IA 期の症例で有意に予後良好であった $(\mathrm{p}<0.001)$. 結論．異時性肺癌においても病理病 期 IA 期の症例は極めて良好な治療成績が得られるため, 早期発見のためにも慎重な術後フォローアップとともに, 全 身状態や残存肺機能の基準を満たせば積極的に手術を行うべきと考えられる。（肺癌．2007;47:239-244）

索引用語 —— 異時性肺癌, 治療, 予後

\section{Surgical Treatment for Metachronous Lung Cancers}

\author{
Kenji Ono; Kenji Sugio; Manabu Yasuda1; Masakazu Sugaya ${ }^{1}$; \\ Hidetaka Uramoto ${ }^{1}$; Takeshi Hanagiri ${ }^{1}$; Kosei Yasumoto ${ }^{1}$
}

\begin{abstract}
Objective. Surgical treatment for metachronous lung cancers should be determined based on curability as well as residual pulmonary function. We reviewed the clinicopathological background, surgical procedure, and corresponding prognoses of patients with metachronous lung cancers. Patients. Of 815 consecutive patients who underwent pulmonary resection for primary lung cancer between April 1994 and December 2005, 22 patients (2.7\%) were found to have metachronous lung cancers. Results. The first primary cancer was p-stage IA in 11 patients, pstage IB in 5, p-stage IIB in 1, p-stage IIIA in 4, and p-stage IV in 1 . The second primary cancer was p-stage IA in 14 patients, p-stage IB in 3, p-stage IIB in 2, p-stage IIIA in 1, and p-stage IIIB in 2. Average maximal tumor diameter of the first primary cancer $(31.8 \mathrm{~mm} ; 12-77 \mathrm{~mm})$ was greater than that of the second primary cancer $(19.3 \mathrm{~mm} ; 5-50 \mathrm{~mm})$ with statistical significance $(p=0.001)$. The surgical procedures for the first primary cancer were lobectomy or more extensive resection in all patients, while those for the second primary cancer were limited operation in 15 patients in order to retain residual pulmonary function. The 5 -year survival rate after the second resection was $63.9 \%$. When patients were classified into 2 groups by the pathological stage of the second primary cancer, the 5-year survival rate of patients with a second primary cancer of p-stage IA (92.9\%) was greater than that of patients with the second primary cancer of p-stage IB or more advanced diseases $(0 \%)$, with a significance level of $\mathrm{p}<0.001$. Conclusion. Patients
\end{abstract}

1 産業医科大学第 2 外科.

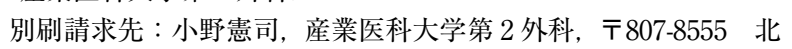
九州市八幡西区医生ヶ丘 1-1 (e-mail: kenji2a@med.uoeh-u.ac.jp).

1Second Department of Surgery, School of Medicine, University of Occupational and Environmental Health, Japan.

Reprints: Kenji Ono, Second Department of Surgery, School of
Medicine, University of Occupational and Environmental Health, 1-1 Iseigaoka, Yahatanishi-ku, Kitakyushu 807-8555, Japan (e-mail: kenji2a@med.uoeh-u.ac.jp).

Received December 25, 2006; accepted February 28, 2007.

(C) 2007 The Japan Lung Cancer Society 
with the second primary cancer of p-stage IA can have a favorable outcome even when they have metachronous lung cancers. Thus we conclude that careful follow up should be continued after the first pulmonary resection, and moreover an aggressive surgical treatment is recommended as long as their performance status or residual pulmonary function allows. (JJLC. 2007;47:239-244)

KEY WORDS — Metachronous lung cancers, Surgical treatment, Prognosis

\section{はじめに}

近年肺癌は，各種画像診断の向上に伴う早期発見例の 増加や集学的治療の向上により, 長期生存する症例が増 えてきている。 その術後経過観察中には残存肺に新たな 第二癌の発生を経験することもあり, 多発肺癌か肺内転 移かの診断が困難な症例や，それらの治療方針に難渋す る症例も少なくはない. 特に, 異時性肺癌の外科治療は, 根治性を十分に考慮することはもとより, 術後残存肺機 能も考慮した上でその術式を決定しなければならず，そ れらの診断および治療は非常に重要である.

そこで今回我々は当科で経験した異時性肺癌症例につ いて, 臨床病理学的背景因子と術式, 予後について検討 した.

\section{対象と方法}

1994 年 4 月から 2005 年 12 月までに産業医科大学第 2 外科に抢いて手術を施行した原発性肺癌切除症例は 815 例であり，そのうち，Martini らの定義1（Table 1）によ り, 異時性肺癌と診断した症例は 22 例 $(2.7 \%)$ であった. 男性 16 例, 女性 6 例であり，第一癌の平均年齢は 65.8 (46～76) 歳, 第二癌の平均年齢は $70.2(50 \sim 81)$ 歳であっ た。第一癌手術日から第二癌手術日までの期間は，平均 1619 （376～4410）日であった，組織型別にみると，同一 組織型は 18 例であり, 腺癌 14 例, 扁平上皮癌 4 例であっ た。異なる組織型は 4 例であり, 扁平上皮癌と腺癌が 1

Table 1. Criteria for Diagnosis of Multiple Primary Lung Cancers

Metachronous tumors

A. Histology different

B. Histology the same, if:

1. free interval between cancers at least 2 years or

2. origin from carcinoma in situ or

3. second cancer in different lobe or lung, but:

a. no carcinoma in lymphatics common to both

b. no extrapulmonary metastasis at time of diagnosis

(Martini N et al. J Thorac Cardiovasc Surg. 1975;70:606-612. )
例, 扁平上皮癌と小細胞癌が 1 例, 扁平上皮癌と大細胞 癌が 2 例であった。これらの症例に打いて, 臨床病理学 的背景因子と術式, 予後について, その臨床的特徵を検 討した，生存期間は各々手術日を起点とし，KaplanMeier 法により生存曲線を求め, 予後の差の検定には log-rank test を用いた. また, 2 群間の比較は $\mathrm{t}$ 検定を用 い, いずれの検定に打いても $\mathrm{p}<0.05$ を有意差ありと判 定した.

\section{結 果}

臨床病理学的背景因子, 術式, 予後を Table 2 に示す. 第一癌の病理病期は, IA 期 11 例, IB 期 5 例, IIB 期 1 例, IIIA 期 4 例, IV 期 1 例であり, 第二癌では, IA 期 14 例, IB 期 3 例, IIB 期 2 例, IIIA 期 1 例, IIIB 期 2 例であった，平均最大腫瘍径は第一癌が $31.8(12 \sim 77)$ $\mathrm{mm}$ であったのに対し，第二癌では $19.3(5 \sim 50) \mathrm{mm}$ と第二癌に打いて有意に小さかった $(\mathrm{p}=0.001)$. また, $2 \mathrm{~cm}$ 以下の腺癌における野口分類は第一癌で Type C 3 例, Type D 1 例, Type F 2 例であり, 第二癌では Type A 1 例, Type B 4 例, Type C 3 例, Type E 1 例, Type F 2 例であった. 手術術式は, 標準術式である肺葉切除を 基本としているため, 第一癌の術式は, いずれも肺葉切 除以上であったのに対し，第二癌で肺葉切除を行った症 例は 7 例であった。 その他 15 例は縮小手術であり, 臨床 的リンパ節転移を伴わない最大腫瘍径 $10 \mathrm{~mm}$ 以下の末 梢小型肺癌 9 例に対して積極的縮小手術を行った. 22 例全例完全切除であった。

第二癌術後の 5 年生存率は $63.9 \%$ であり (Figure 1), 他病死を 3 例に認め, 死因はいずれも肺炎であった。 ま た, 今回異時性肺癌と診断した症例の予後は, 第一癌の 病理病期には規定されず (Figure 2), 第二癌の病理病期 と相関していた（Figure 3).

第二癌術後の最大腫瘍径別の 5 年生存率は最大腫瘍径 $20 \mathrm{~mm}$ 以下が $92.9 \%$ であるのに対し, 最大腫瘍径 21 $\mathrm{mm}$ 以上ではいずれも 4 年以内に死亡しており, 最大腫 瘍径 $21 \mathrm{~mm}$ 以上の症例では有意に予後不良であった (Figure 4).また最大腫瘍径 $10 \mathrm{~mm}$ 以下で臨床的リンパ 節転移を伴わない症例に対し積極的縮小手術を行ってい るが, これら 9 例の 5 年生存率は $100 \%$ であり予後良好 
Table 2. Clinicopathological Feature, Surgical Procedure and Prognosis

\begin{tabular}{|c|c|c|c|c|c|c|c|c|c|c|c|c|c|c|}
\hline & & & First cal & ancer & & & & & & Seco & nd cancer & & & \\
\hline Case & Age & Histology & p-stage & $\begin{array}{c}\text { Tumor } \\
\text { size } \\
(\mathrm{mm})\end{array}$ & Noguchi & $\begin{array}{l}\text { Surgical } \\
\text { procedure }\end{array}$ & Histology & p-stage & $\begin{array}{c}\text { Tumor } \\
\text { size } \\
(\mathrm{mm})\end{array}$ & Noguchi & $\begin{array}{c}\text { Interval } \\
\text { (days) }\end{array}$ & $\begin{array}{l}\text { Surgical } \\
\text { procedure }\end{array}$ & Prognosis & Criteria \\
\hline 1 & 46 & $\mathrm{ad}$ & IA & $25 \times 25$ & - & LLL & $\mathrm{ad}$ & IA & $6 \times 4$ & B & 1124 & PartRU * & $\mathrm{A}$ & B-1 \\
\hline 2 & 76 & ad & IIIA & $18 \times 18$ & $\mathrm{D}$ & RUL & ad & IA & $9 \times 8$ & $\mathrm{~F}$ & 663 & $\mathrm{LS}^{6} \mathrm{seg} *$ & $\mathrm{~A}$ & B-3 \\
\hline 3 & 58 & ad & IA & $20 \times 18$ & $\mathrm{C}$ & LUL & ad & IA & $5 \times 3$ & B & 4410 & RUL & $\mathrm{A}$ & B-1 \\
\hline 4 & 73 & ad & IB & $45 \times 35$ & - & RUL & ad & IA & $10 \times 5$ & $\mathrm{C}$ & 924 & PartLU* & $\mathrm{A}$ & B-1 \\
\hline 5 & 55 & ad & IIIA & $38 \times 32$ & - & LUL & ad & IA & $17 \times 12$ & B & 2737 & RUL & $\mathrm{A}$ & B-1 \\
\hline 6 & 60 & $\mathrm{ad}$ & IA & $15 \times 13$ & $\mathrm{~F}$ & RUL & $\mathrm{ad}$ & IA & $9 \times 8$ & B & 1403 & PartLU * & $\mathrm{A}$ & B-1 \\
\hline 7 & 56 & ad & IA & $26 \times 24$ & - & RUL & ad & IA & $18 \times 15$ & $\mathrm{~F}$ & 2196 & RML & $\mathrm{A}$ & B-1 \\
\hline 8 & 65 & $\mathrm{ad}$ & IA & $17 \times 13$ & $\mathrm{~F}$ & RUL & $\mathrm{ad}$ & IA & $8 \times 7$ & $\mathrm{C}$ & 1858 & $\mathrm{RS}^{6}$ seg * & $\mathrm{A}$ & B-1 \\
\hline 9 & 57 & ad & IIIA & $34 \times 24$ & - & RUL & ad & IA & $10 \times 10$ & A & 903 & PartRL * & $\mathrm{A}$ & B-1 \\
\hline 10 & 73 & ad & IIB & $12 \times 7$ & $\mathrm{C}$ & RUL & $\mathrm{ad}$ & IA & $6 \times 4$ & $\mathrm{E}$ & 387 & PartLL * & A & B-3 \\
\hline 11 & 69 & ad & IA & $25 \times 10$ & - & RUL & ad & IA & $9 \times 5$ & $\mathrm{C}$ & 376 & Lbasalseg * & $\mathrm{A}$ & B-3 \\
\hline 12 & 67 & $\mathrm{sq}$ & IB & $35 \times 25$ & - & LLL & $\mathrm{sq}$ & IA & $16 \times 15$ & - & 2564 & RML & A & B-1 \\
\hline 13 & 62 & $\mathrm{sq}$ & IA & $24 \times 23$ & - & LUL & $\mathrm{sq}$ & IA & $8 \times 7$ & - & 1132 & PartRU * & $\mathrm{A}$ & B-1 \\
\hline 14 & 63 & $\mathrm{ad}$ & IB & $70 \times 60$ & - & LLL & $\mathrm{ad}$ & IB & $50 \times 30$ & - & 3295 & RLL & $\mathrm{CD}$ & B-1 \\
\hline 15 & 63 & $\mathrm{sq}$ & IA & $15 \times 5$ & - & RUL & sq & IB & $32 \times 24$ & - & 2075 & LLL & $\mathrm{CD}$ & B-1 \\
\hline 16 & 71 & $\mathrm{sq}$ & IA & $25 \times 25$ & - & RUL & ad & IIB & $45 \times 40$ & - & 3764 & $\mathrm{LS}^{1-3}$ seg & $\mathrm{CD}$ & $\mathrm{A}$ \\
\hline 17 & 74 & $\mathrm{ad}$ & IA & $20 \times 18$ & $\mathrm{C}$ & RLL & $\mathrm{ad}$ & IIIA & $25 \times 18$ & - & 576 & PartLL & $\mathrm{CD}$ & B-3 \\
\hline 18 & 76 & sq & IA & $20 \times 15$ & - & RUL & $\mathrm{sm}$ & IIIB & $30 \times 25$ & - & 1288 & PartRL & $\mathrm{CD}$ & $\mathrm{A}$ \\
\hline 19 & 69 & la & IB & $77 \times 69$ & - & LUL & sq & IIIB & $39 \times 24$ & - & 868 & RUL & $\mathrm{CD}$ & $\mathrm{A}$ \\
\hline 20 & 72 & $\mathrm{sq}$ & IIIA & $55 \times 45$ & - & LUL & sq & IA & $18 \times 14$ & - & 1673 & $\mathrm{RS}^{6}$ seg & $\mathrm{PD}$ & B-1 \\
\hline 21 & 70 & ad & IV & $50 \times 36$ & - & RMLL & $\mathrm{ad}$ & IB & $35 \times 21$ & - & 476 & $\mathrm{LS}^{6}$ seg & $\mathrm{PD}$ & B-3 \\
\hline 22 & 72 & la & IB & $33 \times 24$ & - & RUL & sq & IIB & $23 \times 18$ & - & 921 & PartRL & $\mathrm{PD}$ & $\mathrm{A}$ \\
\hline
\end{tabular}

ad: adenocarcinoma, sq: squamous cell carcinoma, la: large cell carcinoma, sm: small cell carcinoma, Noguchi: Noguchi's classification, Interval: interval between resections, RUL: right upper lobectomy, RML: right middle lobectomy, RLL: right lower lobectomy, RMLL: right middle and lower bilobectomy, LUL: left upper lobectomy, LLL: left lower lobectomy, LS ${ }^{6}$ seg: left $\mathrm{S}^{6}$ segmentectomy, RS ${ }^{6}$ seg: right $\mathrm{S}^{6}$ segmentectomy, LS ${ }^{1-3}$ seg: left upper division segmentectomy, Lbasalseg: left basal segmentectomy, PartRU: partial resection of right upper lobe, PartRL: partial resection of right lower lobe, PartLU: partial resection of left upper lobe, PartLL: partial resection of left lower lobe.

*: intentional limited resection.

A: alive, CD: cancer death, PD: pneumonia death.

Criteria: Martini’s criteria.

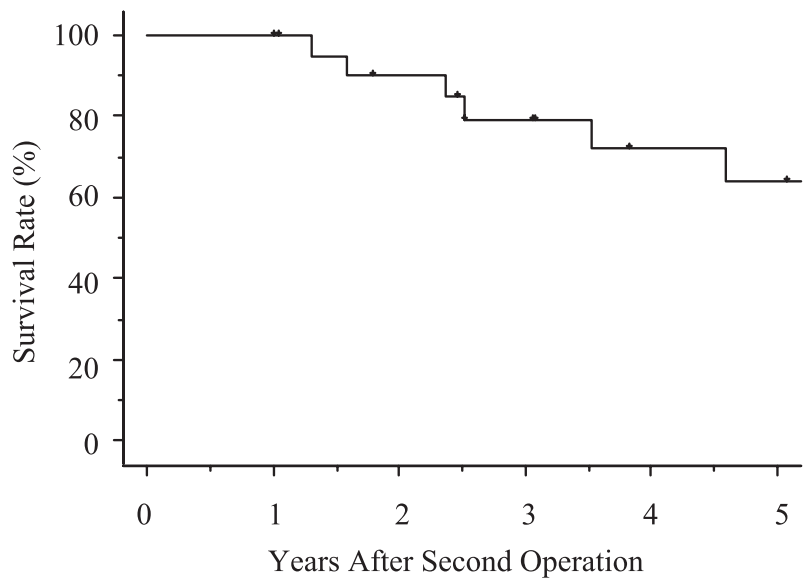

Figure 1. Kaplan-Meier survival curve after second pulmonary resection in metachronous lung cancer.

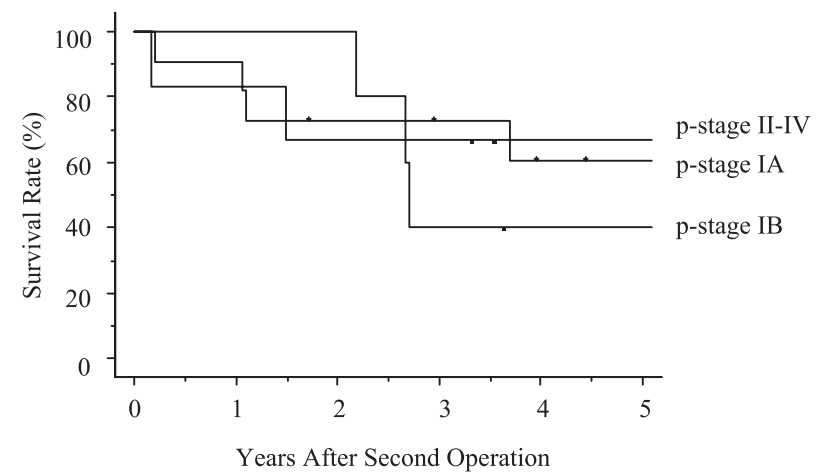

Figure 2. Kaplan-Meier survival curves after second pulmonary resection according to the pathological stage of the first pulmonary lesion in metachronous lung cancer. 


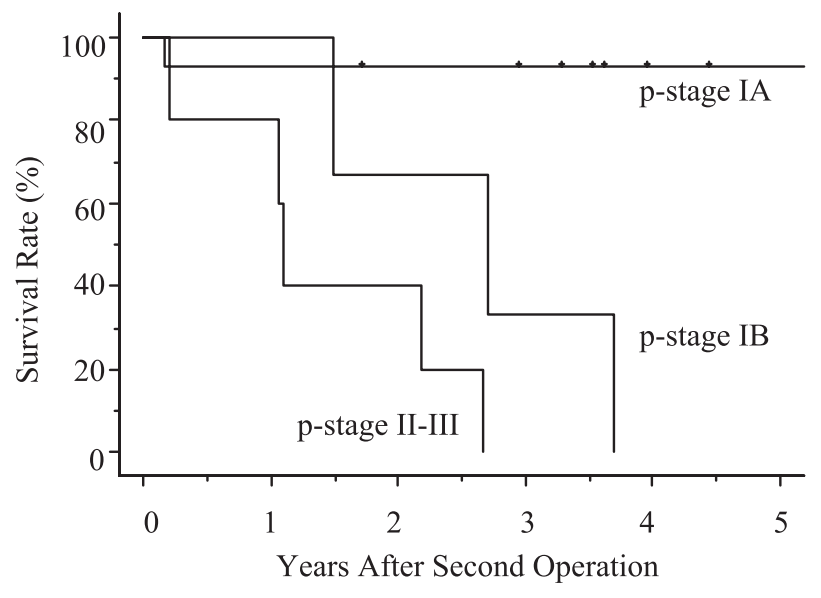

Figure 3. Kaplan-Meier survival curves after second pulmonary resection according to the pathological stage of the second pulmonary lesion in metachronous lung cancer.

であった。

\section{考 察}

近年の各種画像診断法や内視鏡診断法の進歩に伴い, 肺癌の早期発見症例の増加や集学的治療の向上による無 再発期間の延長や予後が向上してきている. そのような 中, 長期生存する症例も増加してきており, それととも に，術後経過観察中に第二癌を発見する症例を経験する ことも多くなってきている.

多発肺癌の頻度は諸家の報告によると, 同時性が 0.7

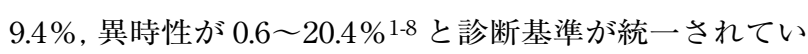
ないこともあり, その発生頻度にはばらつきがある. 多 発肺癌か肺内転移かの鑑別は困難な症例も多く, その診 断基準は, 多くの施設において基本的には Martini らの 定義1に基づいて行われている. しかしながら，それだけ では不十分とし, 病理組織像や治療後の再発形式, さら には p53を中心とした遺伝子解析なども用いられてい る. 9-12 今回の検討では Martini らの定義に基づいて異 時性肺癌と診断したが, 第二癌術後の予後が第一癌の病 理病期ではなく第二癌の病理病期に規定されていたこと から異時性肺癌の診断は概ね正しかったと思われた.

一般的に異時性肺癌は予後不良であるとの報告が多い が, 当科で経験した異時性肺癌 22 例の 5 年生存率は, 第 二癌術後で $63.9 \%$ であり (Figure 1), 第二癌術後の病理 病期別 5 年生存率は IA 期で $92.9 \%$ と良好であったが, IB 期では 4 年以内に, II 期以上では 3 年以内に死亡して いた。第一癌および第二癌とも術死および在院死は認め なかったが，死亡した 9 例のうち，肺炎による死亡を 3 例に認めている。 いずれも軽快退院後に肺炎を発症して おり, 術後 60 日目, 術後 546 日目, 術後 800 日目に死亡

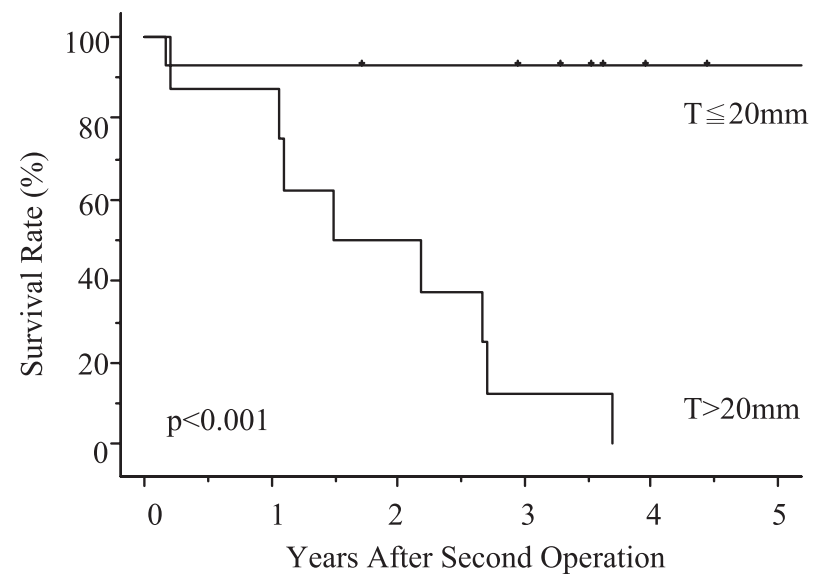

Figure 4. Kaplan-Meier survival curves after second pulmonary resection according to the tumor size of the second pulmonary lesion in metachronous lung cancer.

している.いずれも 70 歳以上と高歯で, 消極的縮小手術 例であり，第二癌術前の performance status が 2 の症 例, 術後予測肺機能で $\mathrm{FEV} 1.0 / \mathrm{m}^{2}$ が少ない症例が含まれ ていた.

また, 最大腫瘍径 $20 \mathrm{~mm}$ 以下の 14 例はいずれも病理 病期 IA 期であり, 1 例に他病死を認めた以外 13 例は生 存しているのに対し, 最大腫瘍径 $21 \mathrm{~mm}$ 以上の 8 例全例 が 4 年以内に死亡しており, そのうち, 6 例は原病死で あった. 最大腫瘍径 $20 \mathrm{~mm}$ 以下の症例は有意に予後良好 であった (Figure 4). 腫瘍径と予後との相関はこれまで にも報告されており, ${ }^{13,14}$ Ishida ら15 は $3 \mathrm{~cm}$ 以下の非小 細胞肺癌において, 腫瘍径が小さいほどリンパ節転移の 頻度も低いと報告している。そのため, より腫瘍径の小 さい段階での発見に努めることは, リンパ節転移を伴わ ないI期症例を発見することにつながり，より早い病期 での治療が行えるため予後の向上につながるものと考え られることょり, 厳重なフォローアップのもと, より小 さい腫瘍径での発見が重要と思われる.

肺葉切除時における術後残存肺機能の予測には, 基本 的には, 切除肺葉のうちで機能している区域支数 16 また は亜区域支数 17 を画像所見と気管支鏡所見から算定し, これに肺機能值を配分することによって評価されてい る. 我々の術後予測残存肺機能の評価法は, Ali らの式 16 を用いて，肺換気血流シンチグラムに基づく左右肺機能 比を考慮している．具体的には, 術後予測残存肺活量が $800 \mathrm{ml} / \mathrm{m}^{2}$ 以上, かつ 1 秒量が $600 \mathrm{ml} / \mathrm{m}^{2}$ 以上となるよ うに術式を選択している．第二癌で手術を施行した 22 例中, 7 例で肺葉切除を行っているが, いずれの症例にお いても重篤な術後呼吸器合併症や呼吸不全は生じていな い.しかしながら, 術後予測残存肺機能は, 特に対側肺 
の手術時において実際の肺機能に比べ過大評価される傾 向にあったり, 左上葉切除後の残存左下葉は著しい肺血 流の低下を生じたりなどが報告されており,18,19 術後残 存肺機能をできるだけ多く残すことが術後の重篤な合併 症の予防につながるものと考えられる.

また, 今回 CT 上, 第二癌の最大腫瘍径 $10 \mathrm{~mm}$ 以下で 画像上明らかなリンパ節転移を伴わない 9 例に対し積極 的縮小手術を行った。平均観察期間 4.2 年でいずれも無 再発生存であり, 5 年生存率 $100 \%$ であった. 第二癌の術 式の選択に関しては, 術後残存肺機能の温存が根治性と ともに重要な因子となってくる. そのため, 腫瘍径が小 さく, リンパ節転移を伴わない症例では肺機能温存の観 点からも縮小手術の適応となりうる可能性がある．特に thin-section CT で ground-glass opacity (GGO) として描 出されるような病変は, GGO の割合が多いほど再発や転 移が少なく, 20 また GGO の割合が $50 \%$ 以上の症例では リンパ節転移や血管浸潤が有意に少なかった 21 との報告 からも，縮小手術の適応となりうるものと思われる. 今 回の検討において, 第一癌術後に第二癌が発生するまで の期間は平均約 4 年 6 ケ月であり, 5 年以内の発生が 14 例 $(63.6 \%), 5$ 年以上が 8 例 $(36.4 \%)$ であったが, 10 年以上経過してからの発生も 2 例 $(9.1 \%)$ に認めた。 ま た, 第一癌術後 15 年経過してから第二癌が発生したとの 報告もあり, 15 肺癌術後のフォローアップは, 再発の確 認目的とともに，異時性肺癌も念頭に置いた長期的な フォローアップが必要である. それにより，肺癌術後に 再発や第二癌を早期に発見できれば予後が向上する可能 性がある。しかし，どのような経過観察法がよいかの大 規模な比較試験はないが, 肺癌切除症例において 3 ケ月 ごとに胸部単純 X 線と 6 ケ月ごとの気管支鏡および胸 腹部 CT 検査で, 再発病巣を無症状のうちに発見するこ とにより予後を改善するという報告 22 とともに，定期的 な検査の必要はないとする報告 23 や, 第二癌の発見とい う観点から, 術後 1 年ごとの胸部 CT 検査は医療経済的 にも有用であるとする報告 24 などがある。 一般的に術後 フォローアップは再発の早期発見を主な目的としてお り，ほとんどの施設で術後 5 年間を目標に行っている. 第二癌が発生する頻度は決して高いとは言えないが, 今 回の検討から, その $36.4 \%$ が 5 年以上経過して発生して いることも考慮に入れての経過観察が必要であり, 早期 発見に努める必要がある.

\section{REFERENCES}

1. Martini N, Melamed MR. Multiple primary lung cancers. J Thorac Cardiovasc Surg. 1975;70:606-612.

2. Martini N, Melamed MR. Occult carcinomas of the lung. Ann Thorac Surg. 1980;30:215-223.
3. Woolner LB, Fontana RS, Cortese DA, et al. Roentgenographically occult lung cancer: pathologic findings and frequency of multicentricity during a 10-year period. Mayo Clin Proc. 1984;59:453-466.

4. 斎藤泰紀, 佐藤雅美, 佐川元保, 他. 胸部 $\mathrm{X}$ 線写真無所 見肺癌における多発癌の診断と治療. 気管支学. 1992;14: 756-759.

5. 新田 隆, 楠 洋子, 瀧藤伸英, 他. 多発肺癌の診断と治 療の現状. 気管支学. 1992;14:765-769.

6. Verhagen AF, van de Wal HJ, Cox AL, et al. Surgical treatment of multiple primary lung cancers. Thorac Cardiovasc Surg. 1989;37:107-111.

7. Rohwedder JJ, Weatherbee L. Multiple primary bronchogenic carcinoma with a review of the literature. $\mathrm{Am}$ Rev Respir Dis. 1974;109:435-445.

8. Mathisen DJ, Jensik RJ, Faber LP, et al. Survival following resection for second and third primary lung cancers. J Thorac Cardiovasc Surg. 1984;88:502-510.

9. 松毛真一, 細川誉至雄, 佐藤一人, 他. 両側多発肺癌症例 の検討. 胸部外科. 2000;53:89-96.

10. 斎藤泰紀, 藤村重文, 佐藤雅美, 他. 多発肺癌の診断と治 療の現状. 日胸. 1993;52:95-101.

11. 土屋了介. 多発肺癌の手術適応. 肺癌の臨床. 1998;1:499503.

12. Mitsudomi T, Yatabe Y, Koshikawa T, et al. Mutations of the P53 tumor suppressor gene as clonal marker for multiple primary lung cancers. J Thorac Cardiovasc Surg. 1997;114:354-360.

13. Port JL, Kent MS, Korst RJ, et al. Tumor size predicts survival within stage IA non-small cell lung cancer. Chest. 2003;124:1828-1833.

14. Martini N, Bains MS, Burt ME, et al. Incidence of local recurrence and second primary tumors in resected stage I lung cancer. J Thorac Cardiovasc Surg. 1995;109:120129.

15. Ishida T, Yano T, Maeda K, et al. Strategy for lymphadenectomy in lung cancer three centimeters or less in diameter. Ann Thorac Surg. 1990;50:708-713.

16. Ali MK, Mountain CF, Ewer MS, et al. Predicting loss of pulmonary function after pulmonary resection for bronchogenic carcinoma. Chest. 1980;77:337-342.

17. Nakahara K, Ohno K, Hashimoto J, et al. Prediction of postoperative respiratory failure in patients undergoing lung resection for lung cancer. Ann Thorac Surg. 1988;46: 549-552.

18. 飯野賢治, 小田 誠, 常塚宣男, 他. 雨側性多発肺癌症例 の検討. 胸部外科. 2002;55:443-450.

19. 近藤晴彦, 吳屋朝幸, 土屋了介, 他. 対側再発肺癌に対す る外科治療. 日呼外会誌. 1988;2:237-242.

20. Kim EA, Johkoh T, Lee KS, et al. Quantification of ground-glass opacity on high-resolution CT of small peripheral adenocarcinoma of the lung: pathologic and prognostic implications. AJR Am J Roentgenol. 2001;177: 1417-1422.

21. Aoki T, Tomoda Y, Watanabe H, et al. Peripheral lung adenocarcinoma: correlation of thin-section CT findings with histologic prognostic factors and survival. Radiology. 2001;220:803-809. 
22. Westeel V, Choma D, Clement F, et al. Relevance of an intensive postoperative follow-up after surgery for nonsmall cell lung cancer. Ann Thorac Surg. 2000;70:1185-1190.

23. Walsh GL, O'Connor M, Willis KM, et al. Is follow-up of lung cancer patients after resection medically indicated and cost-effective? Ann Thorac Surg. 1995;60:1563-1572.

24. Kent MS, Korn P, Port JL, et al. Cost effectiveness of chest computed tomography after lung cancer resection: a decision analysis model. Ann Thorac Surg. 2005;80:12151223. 